\title{
Development of Extruded Functional Snack Foods from Plants and Dairy Ingredients Employing Response Surface Methodology
}

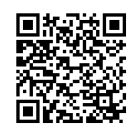

\author{
Mangaraj S*1, Sachidananda Swain ${ }^{2}$ and Deshpande SS ${ }^{1}$ \\ ${ }^{1}$ Senior scientist, and Principal Scientist, Bhopal \\ ${ }^{2}$ Scientist, Division of NRM, ICAR-Central Islands Agricultural Research Institute (CIARI), Bhopal
}

Submission: June 20, 2018; Published: August 29, 2018

*Corresponding author: Mangaraj S, Senior scientist, and Principal Scientist, respectively ICAR-CIAE, Bhopal, Email: sukhdev0108@gmail.com

\section{Abstract}

Although food fortification has been practiced for many years in some countries in the Asian region, notably the more affluent ones, national food-fortification programmed have yet to be fully implemented in areas where this problem abounds. In this paper, we highlighted the development of extruded products based on ICMR recommendations for school going children of age 9-18 year to combat hunger deficiency related disorder. In this regard, corn and rice flour, Defatted soy flour (DFSF), Soy protein isolate (SPI), dairy whitener (DW), mango and spinach were taken as raw materials for the study. The result indicated that there was significant difference between protein, fat, carbohydrate and energy content of extruded products. Protein content increased being maximum (24.5\%) at 20\% of DFSF for DW based product at constant amount of SPI and DW. The significant changes in fat content may be attributed to defatting soy flour that increased the protein solubility and water and oil absorption capacities of the extruded products. High degree of starch gelatinisation at pre-setted machine parameters may be resulted in formation of large insoluble complexes or Maillard compounds causing lesser availability of carbohydrate compounds at higher level of rice and corn flour. Upon model fitting, all the independent variables followed linear model $(\mathrm{P}<0.001)$ except carbohydrate content for mango. High $\mathrm{R}^{2}$ values $\left(\mathrm{R}^{2}>0.92\right)$ and non-significant lack of fit between variables and responses indicated good fits and adequacy for the models. Storage study revealed that there was non-significant increase in moisture and hardness of extruded products.

Keywords: Hardness; Cohesiveness; Stickiness; Springiness; Chewiness; Gumminess; Adhesiveness; Carbohydrates; Proteins; Fat; Minerals; Archidonic acid; Linolenic acid; Obesity; Spinach powder; Mango; Papaya; Calcium

Abbreviations: DFSF: Defatted Soy Flour; SPI: Soy Protein Isolate; DW: Dairy Whitener; FFSF: Full Fat Soy Flour; CIAE: Central Institute of Agricultural Engineering

\section{Introduction}

It has been estimated that 800 million malnourished people exist in developing countries. Development of nutritious foods has been suggested by FAO to combat malnutrition among children for maintaining good health. Snacks contribute an important part of daily nutrient and calorie intake for many consumers. Extruded snack foods have been increasingly gained popularity for providing safe, nutritious, and wholesome food for poor and undernourished populations for the developing world [1-3]. Reasonably low protein content (2.44 to $11.06 \%$ ) in market snacks has been reported by several workers. Thus, high consumption of such snacks could lead to malnutrition in children and obesity, which leads to several diseases in adults [4]. Consumption of snacks as a meal could be applicable if it could either provides protein of 2.5-3.0 g per $100 \mathrm{Kcal}$; or if $10-12 \%$ of total calories are obtained from pro tein; or if the calories gained from consuming the snack was from carbohydrate (55-65\%), fat (20-30\%) and protein 10-15\%). One means for rendering fast food items more nutritious is to fortify them with protein, vitamins, minerals etc. [5].

Cereals mainly rice flour have been popular raw materials for extrusion for food uses mainly because of functional properties, low cost, bland taste, attractive white color, hypoallergenicity and ease of digestion [6]. However, rice is limiting in lysine, the essential amino acid needed for growth but is high in methionine and cystine availability. In contrast, soy protein is high in lysine but low in methionine and cystine. Soy protein contains essential amino acids, most of which are present in amounts that closely match those required for humans. Owing to high protein content, soybean can be effectively utilized for nutritional improvement of cereal based extruded foods $[7,8]$. Currently, there is considerable and increasing interest in the health benefits of soy-containing 
foods; in the role of soy protein in lowering the incidence of certain cancers. Several food products were developed to add up protein content by a combination of cereal and soybean flour [9]. Hence, an optimal incorporation of full fat soy flour (FFSF, $43.6 \%$ protein, $18 \%$ fat) or defatted soy flour (DFSF, $47.2 \%$ protein, $1.0 \%$ fat) in snacks could increase protein quality $[10,11]$. Several researchers developed ready-to-eat fortified products by blending cereals with vegetables and fruits. The incorporation of cauliflower trimmings into ready-to-eat expanded products up to $10 \%$ level was suggested by Stojceska et al. [12]. Altan et al. [13,14] processed the blends of barley flour and tomato pomace; barley flour and grape pomace, corn flour and tomato pomace in a co-rotating twin-screw extruder. Upadhyay et al. $[15,16]$ reported the use of carrot pomace, gram flour and rice flour-based formulation for extrusion studies. However, the range of process variable was too wide.

Among fruits, mangoes contain 10-20 percent sugar and are an important source of vitamin A. Among vegetables, spinach is much richer in protein than other vegetables and it also has high vitamin A content. It is a good source of minerals, but the high content of oxalate leaves the calcium unavailable in diets. So, enabling calcium richness in fortified products, milk is one of the alternatives as a major source of calcium besides other useful properties like easy in digestibility, protein content, linoleic acid (2.1\%), linolenic acid (0.5\%) and archidonic acid (0.14\%).

The main objective of the present investigation is to provide soy-based protein-rich, low-fat nutritious snacks and food. The products have been designed and developed based on ICMR recommendations for school going children of age 9-18 years. This study will provide an additional source of utilization of soy flour in extruded food formulations. The products developed would provide an opportunity for enhancing the use of quality soy protein through popular snack/food products for the school children.

\section{Materials and Methods}

\section{Raw Materials}

Corn, rice and wheat flour, oil, skim milk powder and salt were procured from local market of Bhopal. Soy flour (DFSF, FFSF, SPI) were prepared at ICAR-Central Institute of Agricultural Engineering (CIAE), Bhopal. Mango, papaya, and spinach powder were prepared in food processing laboratory of CIAE. The raw materials were cleaned by sieving and proper amount of the materials were taken by weights. Required amount of water was added to make the feed moisture to required level (10-15\%). All the materials were mixed properly after addition of salt. The mixture was kept $1 \mathrm{hr}$ for pre-conditioning. The twin screw extruder (make BPTL Kolkata) was set with screw speed $400 \mathrm{rpm}$ and temperature of heaters at $70{ }^{\circ} \mathrm{C}$ and $120^{\circ} \mathrm{C}$ for extruder barrel and die. The pressure was maintained between 2059 and $4119 \mathrm{~kg} / \mathrm{cm}^{2}$. The mixture was feed and extruded after which the product was kept in dryer for $1.5 \mathrm{~h}$ to remove moisture. The raw material combinations and their proportions were selected by design expert 7.6 software for different treatment combination of extruded products. Three types of extruded products were extruded based on DW, fruit (mango) and vegetable (spinach) keeping another variables constant in each product.

Some important chemical composition (nutritional values) of all these raw materials taken for the development of extruded snack foods and noodles are given in Table 1.

Table 1: Chemical composition of raw materials used for the development of extruded snack.

\begin{tabular}{|c|c|c|c|c|c|}
\hline Raw materials & Moisture (\%) & Protein (\%) & Fat (\%) & СHO (\%) & Energy (kcal/100 g) \\
\hline Corn flour & 14.9 & 11.0 & 3.6 & 66.0 & 342 \\
\hline Rice flour & 13.7 & 6.8 & 0.5 & 78.0 & 345 \\
\hline Wheat flour & 12.2 & 12.1 & 1.7 & 69.0 & 341 \\
\hline Soybean & 10.0 & 40.0 & 20.0 & 30.0 & 446 \\
\hline DFSF & 7.0 & 50.0 & 1.0 & 47.5 & 430 \\
\hline Guava & 77.0 & 1.1 & 0.2 & 14.4 & 68 \\
\hline Papaya & 90.7 & 0.5 & 0.3 & 11.0 & 43 \\
\hline Mango & 81.0 & 0.6 & 0.4 & 15.0 & 60 \\
\hline Carrot & 86.0 & 0.9 & 0.3 & 9.6 & 41 \\
\hline Spinach & 92.1 & 2.9 & 0.5 & 3.6 & 23 \\
\hline Dairy whiteners & 4.1 & 38.0 & 0.1 & 51.0 & 357 \\
\hline SPI & - & 90.0 & 0.1 & 6.0 & 411 \\
\hline Refined wheat flour & - & 11.0 & 0.9 & 73.9 & 349 \\
\hline
\end{tabular}

\section{Response Surface Methodology}

Response surface methodology (RSM: Mixture Design) was employed to evaluate the effect of different combination with proportion of raw ingredients and their interaction on the nutritional qualities parameters namely protein, fat, carbohydrate and energy content of the extruded snack foods. Corn flour, rice flour, soy flour (DFSF, FFSF, SPI), dairy whitener, mango, papaya, spinach powder etc. were taken as independent (input factor) and quality attributes such as protein content, fat, carbohydrate and energy were considered as dependent parameters. 
Accordingly, mathematical models would be developed to predict the quality parameters of extruded snack foods and noodles under different inputs parameters. Mathematically this can be represented as shown in equation (1)

$$
y=f(x 1, x 2---x n)
$$

Where ' $\mathrm{f}$ ' is the response surface function, ' $\mathrm{y}$ ' is dependent variable (quality parameters) and $\mathrm{x} 1, \mathrm{x} 2, \ldots . \mathrm{xn}$ are input factors.

To approximate the function 'f', second order polynomial equation of the following form was assumed (equation 2).

$$
y=b_{0}+b_{1} x_{1}+b_{2} x_{2}+b_{11} x_{1}^{2}+b_{22} x_{2}^{2}+b_{12} x_{1} x_{2}
$$

Where, $\mathrm{y}$ is the predicted response (dependent variables); b0, b1, b2, b11, b12 and b22 are the regression coefficients; and x1, $\mathrm{x} 2, \ldots . . \mathrm{xn}$ are the coded value of independent variables which are linearly related by the following equation (3) with the original values [17-19].

$$
x_{i}=\frac{2\left(X_{i}-X_{i}^{m}\right)}{X_{i}^{d}}
$$

Where, $\mathrm{X}_{\mathrm{i}}$ is actual value in original units, $\mathrm{Xi}^{\mathrm{m}}$ is mean of maximum and minimum values, $\mathrm{Xi}^{\mathrm{d}}$ is the difference between maxi- mum and minimum values, $\mathrm{x}_{\mathrm{i}}$ is the coded values of independent variables.

\section{Mixture Design for Development of Extruded Products}

Mixture design was used for optimization of different proportion of raw materials namely corn flour, rice flour, DFSF, SPI, fruits, vegetable and dairy whiteners for development of extruded functional food. The range of the percentage of materials taken mixture design has been given in Table 2 .

Table 2: Range of independent parameters.

\begin{tabular}{|c|c|c|c|}
\hline \multicolumn{2}{|c|}{ Constraints } & \multirow{2}{*}{ Lower Limit } & Upper Limit \\
\cline { 1 - 2 } Name & Goal & & 50 \\
\hline A: Corn & is in range & 30 & 50 \\
\hline B: Rice & is in range & 30 & 20 \\
\hline C: DFSF & is in range & 5 & 10 \\
\hline D: SPI & is in range & 5 & 15 \\
\hline Fruits, Vegetable, DW & & & \\
\hline
\end{tabular}

\section{Extrusion Process}

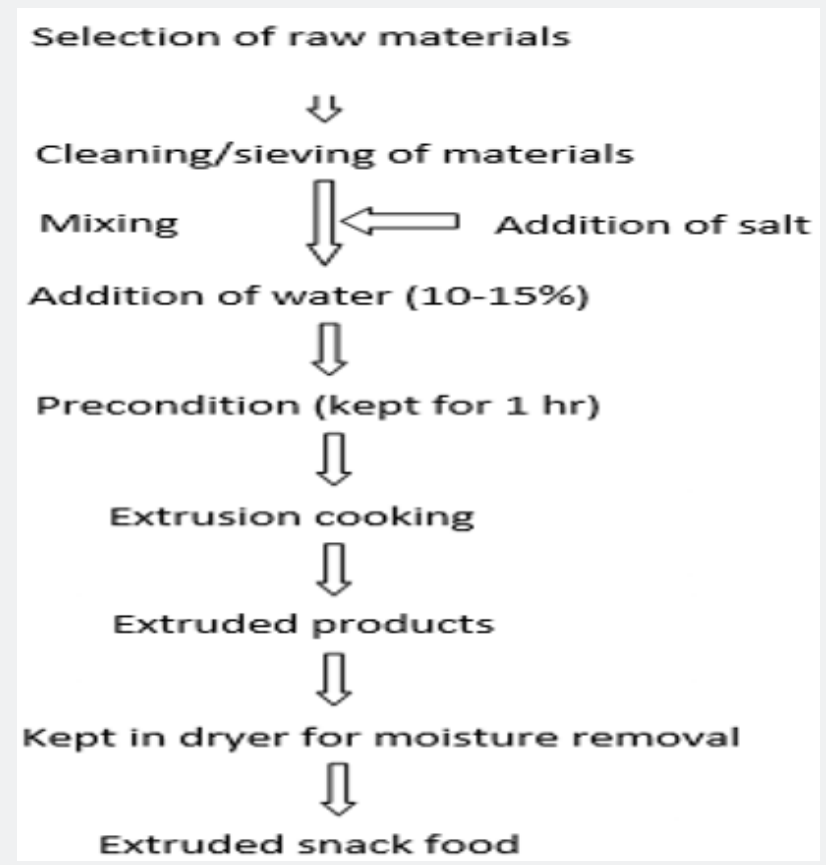

Figure 1: Flow chart for the development of extruded food product.

The twin screw extruder (make BPTL Kolkata) was started 1 $\mathrm{h}$ before the start of experimentation to heat the barrel and die. The flow chart is given in Figure 1. The mixture was fed to the extruder and extruded (Figure 2). The product obtained was kept in dryer for one a half hour to remove moisture. The feed rate was calculated by dividing the raw material fed through feeder and the amount of material fed in 1 min is collected. The extruded prod- ucts developed using various combination and proportion of raw ingredients (S-1: corn + rice + DFSF + DW + SPI; S-2: corn + rice + DFSF + carrot + SPI; S-3: corn + rice + DFSF + spinach + SPI; S-4: corn + rice + DFSF + mango + SPI and control: corn + rice) are shown in Figure 3. The extrusion processing parameters were set to produce extruded functional foods is mentioned in Table 3. 


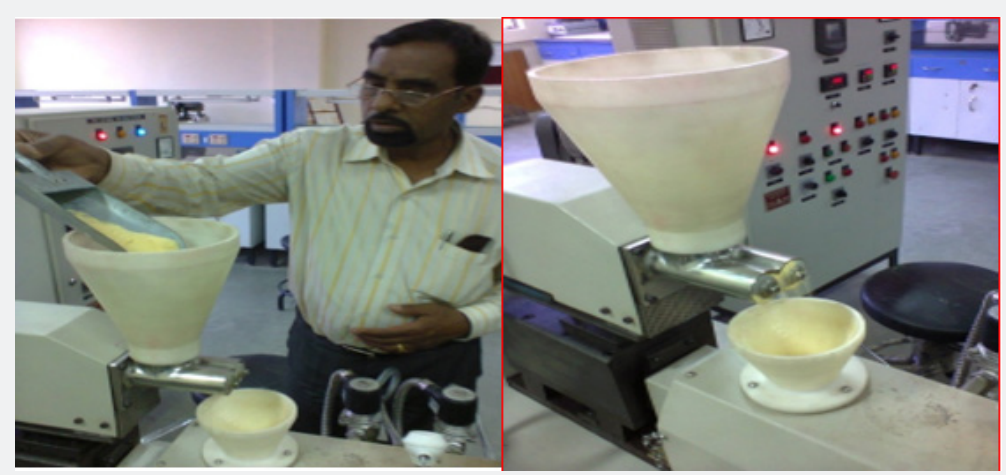

Figure 2: Feeding sample in the extruder.

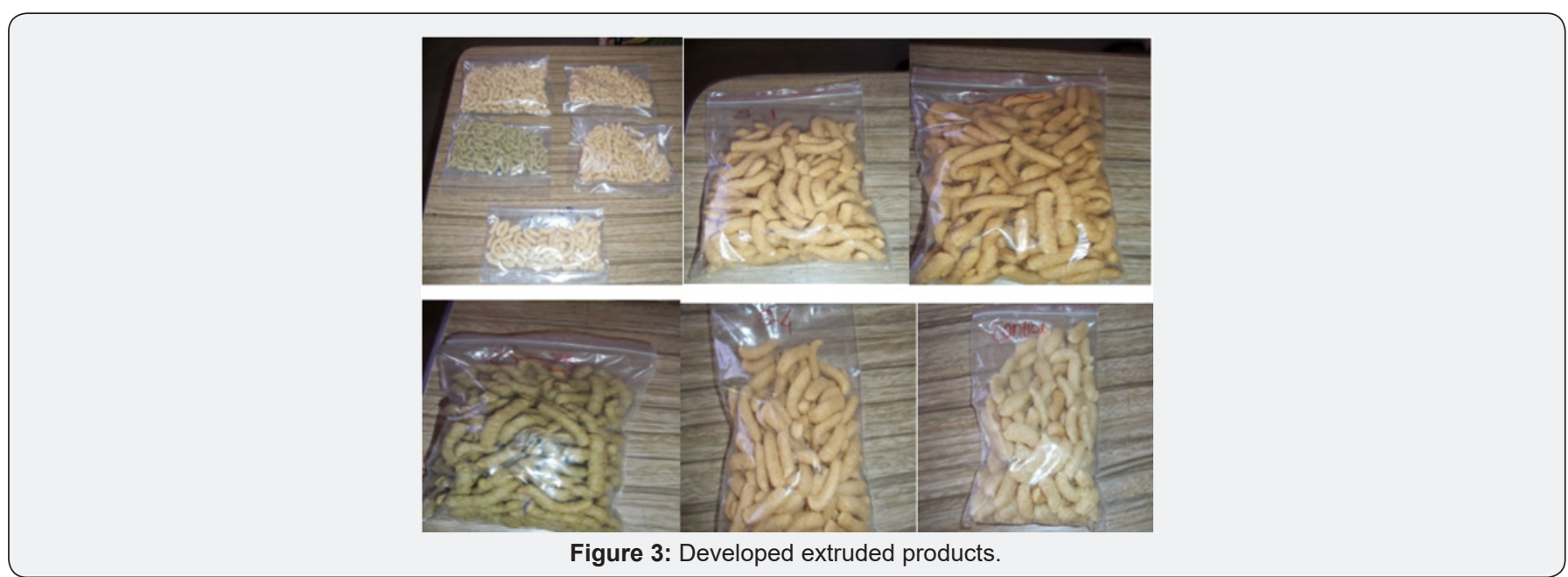

Table 3: Extrusion processing parameters for development of extruded snack foods.

\begin{tabular}{|c|c|}
\hline Parameters & Values \\
\hline Screw speed & $400 \mathrm{rpm}$ \\
\hline Temperature (barrel) & Heater-1 (Extruder Barrel): $70{ }^{\circ} \mathrm{C}$ \\
\hline Temperature (die) & Heater- 2 (Die): $120^{\circ} \mathrm{C}$ \\
\hline Pressure & $2059-4119\left(\mathrm{~kg} / \mathrm{cm}^{2}\right)$ \\
\hline Moisture & $10-15 \%$ \\
\hline
\end{tabular}

The different combination with proportion of experimental trials produced by the response surface modelling for the development of extruded products using corn flour, rice flour, DFSF, SPI, dairy whiteners, fruits and vegetables as well as the output parameters are shown in (Table 4-6).

\section{Product Characteristics}

The moisture, fat, protein and ash were estimated using standard AOAC methods (2005) Determination of carbohydrates and calories. A carbohydrate and calories were calculated by subtracting the percentage of moisture, ash, crude protein, fat from 100 and by using factors $4.0,4.0$, and 9.0 to calculate the energy provided by protein, carbohydrates and fat, respectively.

\section{Results and Discussions}

\section{Protein Content}

The protein content of the extruded product ranged between 17.3 and $24.5 \%$ for DW, 17.6 and 25.9\% for mango, and 13.8and $22.0 \%$ for spinach-based products. Protein content of mango-based products, keeping other variables at respective levels was 5.8 and $17.5 \%$ higher than DW and spinach-based products. Using t-test, it was found that mean value of products between DW and mango are statistically significant $\left(\mathrm{P}<0.05, \mathrm{t}_{\text {stat }}=2.00\right)$. However, for other two products (mango and spinach; DW and spinach), the mean values were significant at $1 \%$ level which indicated larger effect on protein content. Higher protein content was due to high level of SPI and DFSF. The models were adjusted for the extruded protein content is presented in the in ANOVA (Tables 7-9) using design expert 7.6. The model is significant $(\mathrm{P}<0.001)$ with high coefficient of determination $\mathrm{R}^{2}(>0.95)$. There was only a 0.01 per cent chance that a model F-Value this large could occur due to noise. Lack of fit is non-significant $(\mathrm{P}>0.49-0.85)$ showed that model was adequate to fit into independent variables for getting desirable parameter of high accuracy. The regression equation describing the effect of the process variables on protein of extruded product in terms of actual level of the variables are given as: 


\section{Journal of Dairy \& Veterinary Sciences}

Table 4: Treatment combinations using Design Expert 7.6 (DW based combinations).

\begin{tabular}{|c|c|c|c|c|c|c|c|c|}
\hline \multicolumn{5}{|c|}{ Input parameter } & \multicolumn{4}{|c|}{ Output parameter } \\
\hline Corn (g) & Rice (g) & DFSF (g) & SPI (g) & Dairy Whiteners (DW) & Protein (g) & Fat (g) & CHO (g) & Energy kcal \\
\hline 30.00 & 39.68 & 15.30 & 5.00 & 10.00 & 19.31 & 2.16 & 65.19 & 357.54 \\
\hline 30.84 & 30.20 & 20.00 & 8.93 & 10.03 & 24.50 & 2.22 & 60.15 & 358.58 \\
\hline 30.00 & 36.62 & 13.45 & 9.92 & 10.00 & 22.66 & 2.14 & 62.09 & 358.21 \\
\hline 41.10 & 30.00 & 10.00 & 8.89 & 10.00 & 20.89 & 2.46 & 62.93 & 357.45 \\
\hline 30.00 & 30.02 & 19.98 & 5.00 & 14.99 & 21.73 & 3.12 & 62.03 & 363.18 \\
\hline 35.77 & 30.00 & 19.22 & 5.00 & 10.00 & 20.98 & 2.374 & 62.94 & 357.09 \\
\hline 30.00 & 42.97 & 10.00 & 7.02 & 10.00 & 18.71 & 2.12 & 65.73 & 356.86 \\
\hline 30.00 & 42.24 & 10.00 & 5.00 & 12.76 & 17.41 & 2.64 & 66.59 & 359.76 \\
\hline 44.99 & 30.00 & 10.00 & 5.00 & 10.00 & 17.68 & 2.87 & 65.51 & 358.62 \\
\hline 30.00 & 35.48 & 15.37 & 6.75 & 12.39 & 20.97 & 2.88 & 63.18 & 362.56 \\
\hline 30.00 & 37.69 & 10.00 & 9.17 & 13.14 & 20.93 & 2.97 & 63.22 & 363.42 \\
\hline 30.77 & 34.87 & 11.42 & 7.93 & 15.00 & 20.65 & 3.35 & 63.05 & 365.08 \\
\hline 30.77 & 34.87 & 11.42 & 7.93 & 15.00 & 20.65 & 3.35 & 63.05 & 365.08 \\
\hline 35.11 & 34.06 & 10.27 & 10.00 & 10.54 & 21.49 & 2.65 & 62.53 & 359.97 \\
\hline 42.00 & 30 & 10.00 & 5.00 & 12.98 & 17.85 & 3.28 & 65.09 & 361.35 \\
\hline 30.00 & 30 & 15.93 & 9.98 & 14.07 & 24.02 & 3.13 & 59.98 & 364.26 \\
\hline 33.12 & 38.29 & 11.00 & 7.56 & 10.00 & 19.60 & 2.45 & 64.52 & 358.60 \\
\hline 35.92 & 31.94 & 13.85 & 5.49 & 12.78 & 19.52 & 3.08 & 63.95 & 361.67 \\
\hline 38.91 & 33.68 & 10.46 & 5.08 & 11.84 & 17.82 & 2.98 & 65.50 & 360.16 \\
\hline 30.00 & 30.01 & 19.98 & 5.00 & 14.99 & 21.62 & 3.35 & 62.03 & 364.85 \\
\hline 37.11 & 37.87 & 10.00 & 5.00 & 10.00 & 17.30 & 2.58 & 66.45 & 358.28 \\
\hline 42.15 & 30 & 12.83 & 5.00 & 10.00 & 18.66 & 2.75 & 64.72 & 358.35 \\
\hline 30.00 & 30 & 15.93 & 9.98 & 14.07 & 24.09 & 3.13 & 59.98 & 364.54 \\
\hline 30.00 & 42.24 & 10.00 & 5.00 & 12.75 & 17.37 & 2.71 & 66.59 & 360.36 \\
\hline 30.00 & 39.68 & 15.30 & 5.00 & 10.00 & 19.13 & 2.24 & 65.19 & 357.54 \\
\hline
\end{tabular}

Table 5: Treatment combinations using Design Expert 7.6 (mango based combinations).

\begin{tabular}{|c|c|c|c|c|c|c|c|c|}
\hline \multicolumn{5}{|c|}{ Input parameter } & \multicolumn{4}{|c|}{ Output parameter } \\
\hline Corn & Rice & DFSF & SPI & Mango & Protein & Fat & СHO & Energy kcal \\
\hline 32.81 & 31.52 & 10.66 & 10.00 & 14.99 & 21.96 & 1.42 & 60.67 & 343.41 \\
\hline 30.00 & 43.72 & 10.00 & 5.00 & 11.26 & 17.65 & 1.35 & 67.46 & 352.74 \\
\hline 30.00 & 42.31 & 14.46 & 5.00 & 8.22 & 19.63 & 1.39 & 67.56 & 361.33 \\
\hline 30.15 & 30.10 & 20.00 & 9.99 & 9.73 & 25.93 & 1.41 & 60.50 & 358.47 \\
\hline 31.04 & 38.38 & 20.00 & 5.33 & 5.23 & 22.36 & 1.46 & 66.80 & 369.87 \\
\hline 30.00 & 38.77 & 16.66 & 9.55 & 5.00 & 24.50 & 1.39 & 65.09 & 370.97 \\
\hline 30.01 & 30.00 & 19.98 & 5.00 & 14.99 & 21.87 & 1.40 & 61.21 & 344.98 \\
\hline 30.01 & 30.00 & 19.98 & 5.00 & 14.99 & 21.58 & 1.40 & 60.46 & 340.84 \\
\hline 32.81 & 31.52 & 10.66 & 10.00 & 14.99 & 22.12 & 1.40 & 59.92 & 340.84 \\
\hline 30.94 & 35.29 & 13.78 & 9.65 & 10.32 & 23.29 & 1.37 & 62.04 & 353.76 \\
\hline 36.07 & 34.11 & 16.29 & 7.01 & 6.50 & 22.56 & 1.56 & 64.83 & 363.70 \\
\hline 40.77 & 33.39 & 10.74 & 10.00 & 5.07 & 23.11 & 1.66 & 65.01 & 367.49 \\
\hline 40.77 & 33.39 & 10.74 & 10.00 & 5.07 & 23.11 & 2.00 & 65.01 & 370.57 \\
\hline 30.00 & 49.98 & 10.00 & 5.00 & 5.00 & 18.19 & 1.68 & 67.56 & 358.22 \\
\hline 35.24 & 39.38 & 11.94 & 7.384 & 6.035 & 21.12 & 1.85 & 65.66 & 363.81 \\
\hline 39.41 & 30.00 & 12.34 & 7.49 & 10.74 & 21.26 & 1.97 & 62.02 & 350.98 \\
\hline 30.00 & 41.29 & 10.00 & 9.70 & 8.99 & 21.86 & 1.66 & 63.43 & 356.17 \\
\hline
\end{tabular}


Journal of Dairy \& Veterinary Sciences

\begin{tabular}{|l|l|l|l|l|l|l|l|l|}
\hline 49.18 & 30.00 & 10.00 & 5.80 & 5.00 & 20.12 & 2.178 & 66.63 & 366.63 \\
\hline 45.78 & 30.00 & 10.00 & 5.00 & 9.20 & 19.05 & 2.07 & 65.09 & 355.22 \\
\hline 31.03 & 34.61 & 18.45 & 8.16 & 7.73 & 24.53 & 1.66 & 61.92 & 360.80 \\
\hline 41.30 & 38.69 & 10.00 & 5.00 & 5.00 & 19.11 & 1.93 & 69.50 & 371.93 \\
\hline 30.00 & 43.721 & 10.00 & 5.00 & 11.26 & 18.24 & 1.58 & 67.01 & 355.30 \\
\hline 39.56 & 30.40 & 20.00 & 5.00 & 5.02 & 23.06 & 1.95 & 65.71 & 372.69 \\
\hline 30.00 & 49.98 & 10.00 & 5.00 & 5.00 & 18.63 & 1.58 & 68.85 & 364.25 \\
\hline 44.57 & 30.00 & 15.41 & 5.00 & 5.00 & 21.43 & 2.07 & 66.95 & 372.25 \\
\hline
\end{tabular}

Table 6: Treatment combinations using Design Expert 7.6 (spinach based combinations).

\begin{tabular}{|c|c|c|c|c|c|c|c|c|}
\hline \multicolumn{5}{|c|}{ Input parameter } & \multicolumn{4}{|c|}{ Output parameter } \\
\hline Corn & Rice & DFSF & SPI & Spinach & Protein & Fat & СHO & Energy kcal \\
\hline 44.38 & 35.59 & 10.02 & 5.00 & 5.00 & 14.77 & 2.15 & 68.20 & 351.31 \\
\hline 30.00 & 30.00 & 20.00 & 5.00 & 14.98 & 17.69 & 1.80 & 58.43 & 320.72 \\
\hline 30.00 & 45.30 & 10.00 & 9.67 & 5.00 & 18.04 & 1.69 & 66.27 & 352.49 \\
\hline 36.33 & 32.72 & 10.79 & 5.15 & 15.00 & 14.38 & 1.93 & 61.21 & 319.79 \\
\hline 30.24 & 30.00 & 16.72 & 8.29 & 14.73 & 19.13 & 1.98 & 57.32 & 323.69 \\
\hline 37.74 & 42.25 & 10.00 & 5.00 & 5.00 & 14.48 & 2.16 & 69.00 & 353.41 \\
\hline 38.50 & 35.20 & 13.49 & 5.00 & 7.80 & 15.65 & 2.21 & 65.42 & 344.22 \\
\hline 39.97 & 30.00 & 10.00 & 9.99 & 10.01 & 18.36 & 2.21 & 61.05 & 337.66 \\
\hline 30.00 & 47.29 & 10.00 & 5.00 & 7.69 & 13.89 & 1.92 & 67.90 & 344.54 \\
\hline 32.77 & 33.84 & 13.99 & 7.63 & 11.74 & 17.61 & 2.03 & 60.87 & 332.30 \\
\hline 30.00 & 38.45 & 15.06 & 5.00 & 11.47 & 15.75 & 1.96 & 63.04 & 332.90 \\
\hline 45.08 & 30.00 & 10.00 & 5.00 & 9.90 & 14.43 & 2.3 & 64.43 & 337.04 \\
\hline 36.61 & 30.00 & 15.79 & 7.89 & 9.69 & 18.81 & 2.11 & 61.04 & 338.47 \\
\hline 39.97 & 30.00 & 10.00 & 9.99 & 10.01 & 18.36 & 2.17 & 61.05 & 337.23 \\
\hline 49.13 & 30.00 & 10.00 & 5.85 & 5.00 & 15.34 & 2.46 & 66.97 & 351.42 \\
\hline 32.00 & 32.60 & 20.00 & 9.99 & 5.39 & 22.05 & 1.98 & 61.51 & 352.15 \\
\hline 36.33 & 32.72 & 10.79 & 5.15 & 15.00 & 14.04 & 2.09 & 61.21 & 319.89 \\
\hline 30.00 & 45.30 & 10.00 & 9.67 & 5.00 & 17.69 & 1.85 & 66.27 & 352.58 \\
\hline 30.00 & 45.76 & 14.21 & 5.00 & 5.00 & 15.51 & 1.90 & 68.25 & 352.16 \\
\hline 30.33 & 34.51 & 10.15 & 9.99 & 15.00 & 17.56 & 1.88 & 58.40 & 320.81 \\
\hline 32.70 & 40.86 & 10.00 & 7.31 & 9.11 & 15.66 & 1.87 & 64.70 & 338.32 \\
\hline 45.08 & 30.00 & 10.00 & 5.00 & 9.90 & 14.23 & 2.26 & 64.43 & 335.06 \\
\hline 34.58 & 32.94 & 20.00 & 6.73 & 5.73 & 19.44 & 1.99 & 63.50 & 349.73 \\
\hline 45.04 & 30.00 & 14.95 & 5.00 & 5.00 & 16.45 & 2.28 & 66.16 & 351.09 \\
\hline 32.00 & 32.60 & 20.00 & 9.99 & 5.39 & 22.06 & 1.90 & 61.51 & 351.44 \\
\hline
\end{tabular}

Table 7: ANOVA for Linear Mixture Model (DW).

\begin{tabular}{|c|c|c|c|c|c|}
\hline & \multicolumn{5}{|c|}{ Response 1 Protein } \\
\hline & \multicolumn{5}{|c|}{ Mixture Component Coding is L_Pseudo } \\
\hline Source & Squares & Df & Square & F-Value & Prob> F \\
\hline Model & 111.8898 & 4 & 27.97245 & 5392.277 & $<0.0001^{* * *}$ \\
\hline Linear Mixture & 111.8898 & 4 & 27.97245 & 5392.277 & $<0.0001^{* * *}$ \\
\hline Residual & 0.10375 & 20 & 0.005188 & & 0.4983 \\
\hline Lack of Fit & 0.07965 & 15 & 0.00531 & 1.10166 & \\
\hline Pure Error & 0.0241 & 5 & 0.00482 & & \\
\hline Cor Total & 111.9935 & 24 & & & \\
\hline
\end{tabular}


*** Significant at $1 \%$ level

Table 8: ANOVA for Linear Mixture Model on protein content (Mango).

\begin{tabular}{|c|c|c|c|c|c|c|}
\hline \multicolumn{7}{|c|}{ ANOVA for Linear Mixture Model } \\
\hline \multicolumn{7}{|c|}{ *** Mixture Component Coding is L_Pseudo. $* * *$} \\
\hline \multicolumn{7}{|c|}{ Analysis of variance table [Partial sum of squares - Type III] } \\
\hline & Sum of & & Mean & $\mathrm{F}$ & p-value & \\
\hline Source & Squares & Df & Square & Value & Prob> F & \\
\hline Model & 112.3298 & 4 & 28.08244 & 682.0435 & $<0.0001$ & Significant \\
\hline Linear Mixture & 112.3298 & 4 & 28.08244 & 682.0435 & $<0.0001$ & \\
\hline Residual & 0.823479 & 20 & 0.041174 & & & \\
\hline Lack of Fit & 0.501625 & 15 & 0.033442 & 0.519517 & 0.8504 & not significant \\
\hline Pure Error & 0.321854 & 5 & 0.064371 & & & \\
\hline Cor. Total & 113.1532 & 24 & & & & \\
\hline
\end{tabular}

Table 9: ANOVA for Linear Mixture Model on protein content (Spinach).

\begin{tabular}{|c|c|c|c|c|c|c|}
\hline \multicolumn{7}{|c|}{$* * *$ Mixture Component Coding is L_Pseudo. $* * *$} \\
\hline & Sum of & & Mean & F & p-value & Prob> F \\
\hline Source & Squares & Df & Square & Value & $<0.0001$ & Significant \\
\hline Model & 131.6551 & 4 & 32.91377 & 1535.909 & $<0.0001$ & \\
\hline Linear Mixture & 131.6551 & 4 & 32.91377 & 1535.909 & & not significant \\
\hline Residual & 0.42859 & 20 & 0.02143 & & & \\
\hline Lack of Fit & 0.292059 & 15 & 0.019471 & 0.713043 & & \\
\hline $\mathrm{R}^{2}$ & & & & & & \\
\hline Pure Error & 0.136532 & 5 & 0.027306 & & & \\
\hline Cor Total & 132.0837 & 24 & & & & \\
\end{tabular}

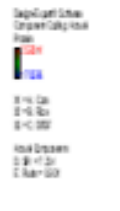

a) DW
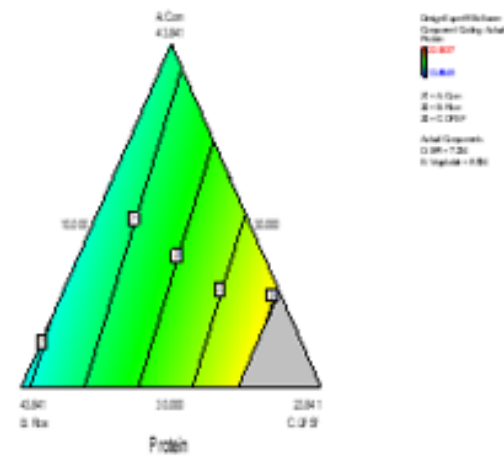

b) mango

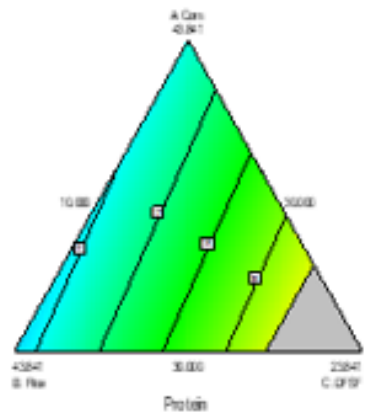

c) spinach

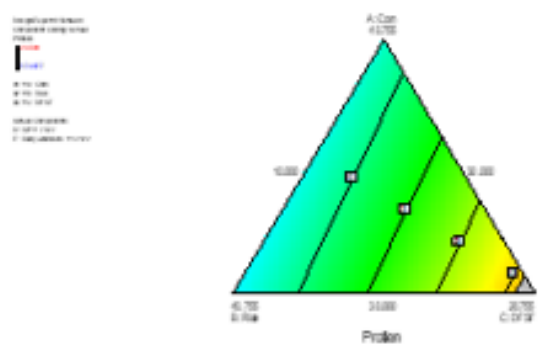

Figure 4: Effect of rice, DFSF and corn on protein content of extruded product. 
Final Equation in Terms of Actual Components:

Protein $=0.104533^{*}$ Corn $+0.064893^{*} \quad$ Rice $+0.472722^{*}$ DFSF+0.903641* SPI+0.174343*Dairy whiteners. (4) for DW.

Protein $=0.14925 *$ Corn $+0.089042 * \quad$ Rice $+0.49009 *$ $\mathrm{DFSF}+0.87187 *$ SPI $\quad+0.02722 *$ Fruits $\quad$ (5) for mango.

Protein $=\quad 0.089208^{*} \quad$ Corn $+0.049002^{*}$ Rice+0.446145*DFSF+0.86918* SPI+0.009491* Vegetable for spinach.

Model graph (Figure 4) shows the response plot of rice, DFSF and corn on protein content by taking a constant amount of SPI (7.12) and dairy whitener (12.12). As DFSF and SPI were the main contributor of protein, it is revealed from the graph $(1, a)$ that with the increase in DFSF, protein content increased being maximum (24.5\%) at $20 \%$ of DFSF for DW based product. Similar behavior was also found for mango and spinach-based products. The result agrees with the report by Jha and Prasad \& Sudha et al. [20,21] who revealed that inclusion of soy flour and whey protein concentrate in instant vermicelli not only enhanced their protein content and in vitro protein digestibility but also reduced the fat uptake in noodles. As SPI and DFSF are the main source of protein in the product, as described above, high protein content of the products is also reflected in respective regression coefficients [SPI $(>0.85)$ and DFSF (>0.45)] (eq. 4-6). It was found that protein content was maximum at 31 and $34 \%$ of rice and corn flour after which it decreased (as per table, but not revealed in graphs).

\section{Fat Content}

Fat content varied from 2.7 to $3.1 \%$ for DW, 1.3 to $2.1 \%$ for mango and 1.6 to $2.4 \%$ for spinach based extruded product. There were little variations in fat content because the entire ingredient had lower amount of fat. Using student's t-test, it was found that mean value of products was statistically significant $(\mathrm{P}<0.001$, $\mathrm{t}_{\text {stat }}=11.21$ ). Similar behaviors were also found for mango and spinach-based products. The model was adjusted for fat content in this mixture design are presented in ANOVA (Tables 10-12) revealed that all models were significant $(\mathrm{P}<0.001)$ with high $\mathrm{R}^{2}(>0.82)$. The non-significant (0.27) F-value (1.75) of the lack fit indicated the model is adequate for describing the independent parameters for fat content with better accuracy. The regression equation describing the effect of the process variables on the fat content of product in terms of actual level of the variables are given as:

Table 10: ANOVA for Linear Mixture Model on fat content (DW).

\begin{tabular}{|c|c|c|c|c|c|}
\hline \multirow[b]{3}{*}{ Source } & \multicolumn{5}{|c|}{ Response1 Protein } \\
\hline & \multicolumn{5}{|c|}{ Mixture Component Coding is L_Pseudo } \\
\hline & Squares & Df & Square & Value & Prob $>$ F \\
\hline Model & 3.876466 & 4 & 0.969117 & 94.25765 & $<0.0001^{* * *}$ \\
\hline Linear Mixture & 3.876466 & 4 & 0.969117 & 94.25765 & $<0.0001^{* * *}$ \\
\hline Residual & 0.205631 & 20 & 0.010282 & & \\
\hline Lack of Fit & 0.172781 & 15 & 0.011519 & 1.753236 & 0.2783 \\
\hline $\mathrm{R}^{2}$ & 0.9464 & & & & \\
\hline Pure Error & 0.03285 & 5 & 0.00657 & & \\
\hline Cor Total & 4.082097 & 24 & & & \\
\hline
\end{tabular}

Table 11: ANOVA for Linear Mixture Model on fat (mango).

\begin{tabular}{|c|c|c|c|c|c|c|}
\hline \multicolumn{4}{|c|}{ ANOVA for Linear Mixture Model } & & & \\
\hline \multicolumn{5}{|c|}{ *** Mixture Component Coding is L_Pseudo. *** } & & \\
\hline \multicolumn{6}{|c|}{ Analysis of variance table [Partial sum of squares - Type III] } & \\
\hline & Sum of & & Mean & $\mathbf{F}$ & p-value & \\
\hline Source & Squares & $\mathrm{df}$ & Square & Value & Prob> F & \\
\hline Model & 1.408263 & 4 & 0.352066 & 22.82692 & $<0.0001$ & Significant \\
\hline Linear Mixture & 1.408263 & 4 & 0.352066 & 22.82692 & $<0.0001$ & \\
\hline Residual & 0.308466 & 20 & 0.015423 & & & \\
\hline Lack of Fit & 0.219779 & 15 & 0.014652 & 0.826046 & 0.6487 & not significant \\
\hline Pure Error & 0.088687 & 5 & 0.017737 & & & \\
\hline Cor Total & 1.716729 & 24 & & & & \\
\hline
\end{tabular}


Table 12: ANOVA for Linear Mixture Model on fat content (spinach).

\begin{tabular}{|c|c|c|c|c|c|}
\hline \multicolumn{7}{|c|}{ Response } & $\mathbf{3}$ & Fat & \\
\hline \multicolumn{7}{|c|}{ ANOVA for Linear Mixture Model } & \\
\hline \multicolumn{7}{|c|}{ Analysis of variance table [Partial sum of squares - Type III] } \\
\hline
\end{tabular}

Final equation in terms of actual components:

Fat $=0.029013^{*}$ Corn- $0.01306 *$ Rice- $0.01349 *$ DFSF- $0.00466 *$ SPI+0.206028* Dairy whiteners. (7) for DW

Fat $=0.041727 *$

Corn $+0.007691^{*}$

Rice+0.001702DFSF-0.00603* SPI-0.00622* Fruits mango

(8) for

Fat $=0.039179 *$

Corn $+0.008926^{*}$

Rice+0.012931*DFSF+0.007637* SPI+0.011969* Vegetable for spinach

From regression curve (eq. 7-9), it was found that the rice flour, DFSF and SPI (for DW), SPI and fruit (for mango) had negative effect and corn flour and dairy whitener had positive effect on fat content. As fat content mostly depends on dairy whitener as described above is also evident from the regression equation (eq. 4). Fat are generally affected by the corn flour and DFSF but the role was meagre as evident from regression equation. Generally, the protein content is believed to play a role in oil absorption in extruded product. In a qualitative study, Moss et al. (1987) reported that noodles made from high-protein wheat flour absorbed less oil than noodles made from low-protein flour. They proposed that the high oil absorption in low-protein flour noodle was due to the formation of coarse globules during steaming, allowing oil to penetrate easily through the noodle. In our study products having high protein contents were due to protein rich SPI which showed more oil absorption than the low protein samples. Protein content is not the sole factor influencing oil uptake, protein quality also significantly affects free oil absorption in instant noodles [22]. Again, defatting increases the protein solubility and water and oil absorption capacities of the extruded products.

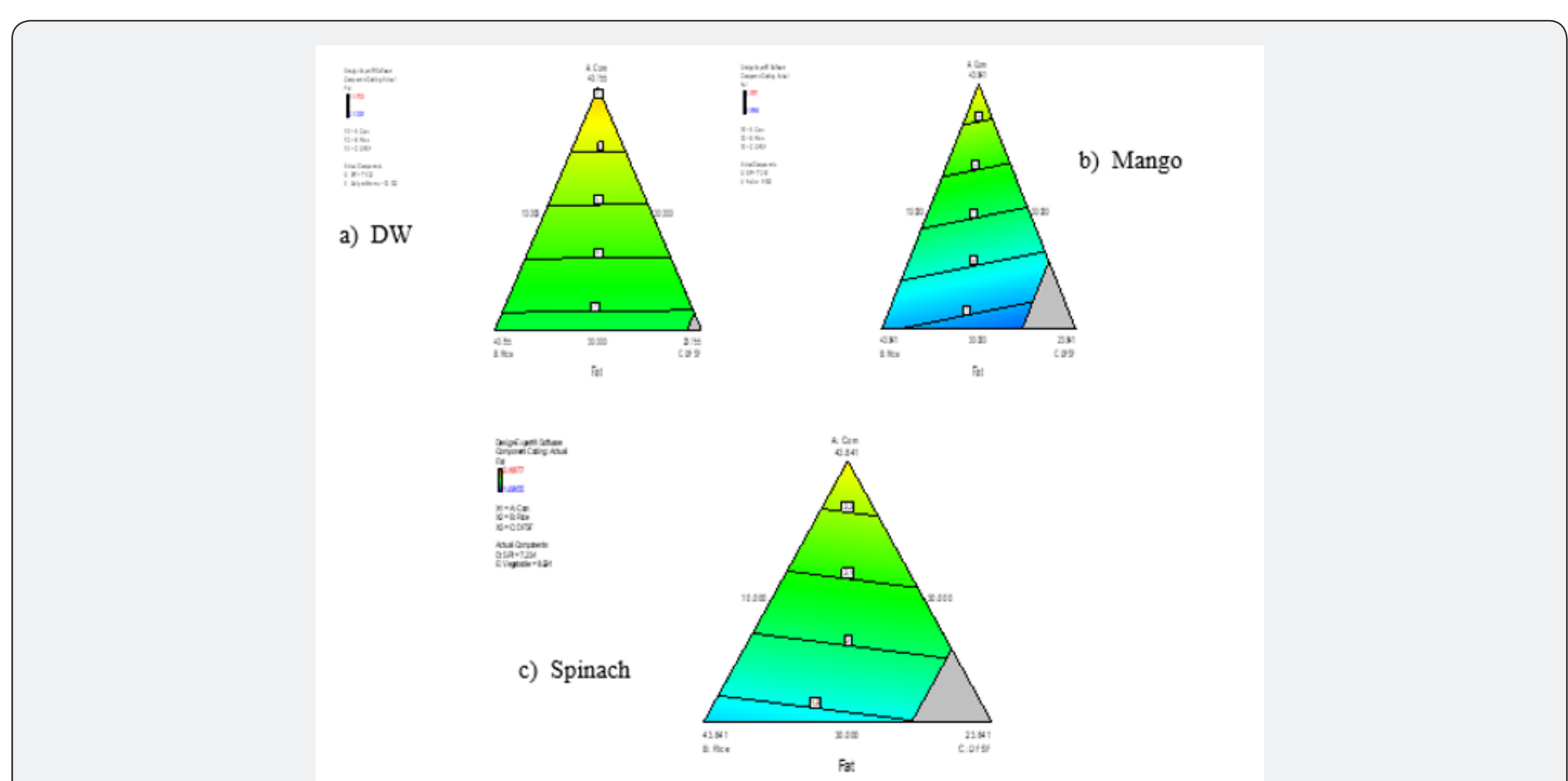

Figure 5: Effect of rice, DFSF and corn on fat content of extruded product. 
The capacity of protein to absorb water and oil is determined by its polar and non-polar amino acids composition, respectively [23]. At high moisture content, the viscosity of the starch would be low, allowing for extensive internal mixing and uniform heating which, in turn, would account for enhanced starch gelatinization; it also may lead to increased water absorption causing high fat absorption also. The high mechanical shear caused breakdown of macromolecules to small molecules with higher solubility. It is clear from the response surface (Figure 5) that oil content in rice, corn and DFSF simultaneously increased the fat content in the products and the extent was more than the individual effects, indicating a synergy. This agrees with the report by Murthy. While elasticity may be critical for finished product qualities, it causes issues in industrial production of dough products, where large heaps of doughs are shaped into thin sheets using sheeting rolls. Increasing the ratio of starch to protein leads to formation of a continuous starch matrix that enables water vapour to expand because starch melt viscosity is lower than protein melt viscosity [24-26]. During moisture removal process, the spaces of water vapour may filled by fat globules causing more fat content in extruded products.

\section{Energy Content}

The energy content of the products ranged from 356 to 365 $\mathrm{kcal} / 100 \mathrm{~g}$ for DW, 340 to $372 \mathrm{kcal} / 100 \mathrm{~g}$ for mango and 319 and $353 \mathrm{kcal} / 100 \mathrm{~g}$ for the extruded product. Using student'st-test, it was found that mean energy content of products using DW and mango were statistically non-significant $\left(\mathrm{P}<0.61, \mathrm{t}_{\text {stat }}=0.5\right)$ while the same was significant using DW and $\operatorname{spinach}\left(\mathrm{P}<0.001, \mathrm{t}_{\text {stat }}=\right.$ 8.36) and spinach and mango $\left(\mathrm{P}<0.001, \mathrm{t}_{\text {stat }}=6.25\right)$. This indicated that mango could be used as energy replacer for DW with reduced cost of final product as the unit cost of DW is much higher than mango. For all the mixtures whatever the level, energy content was significant $(<0.001)$ as shown in (Tables 13-15) with high coefficient of determination $\mathrm{R}^{2}(>0.92)$. The non-significant $(\mathrm{P}>0.22)$ indicated good accuracy of chosen model. The regression equation describing the effect of the process variables on energy content in terms of actual level of the variables are given as:

Table 13: ANOVA for Linear Mixture Model on energy content (DW).

\begin{tabular}{|c|c|c|c|c|c|}
\hline \multirow{2}{*}{} & \multicolumn{5}{|c|}{ Response1 Protein } \\
\hline Source & Squares & Df & Square & Value & Prob> F \\
\hline Model & 180.0435 & 4 & 45.01088 & 78.34945 & $<0.0001$ \\
\hline Linear Mixture & 180.0435 & 4 & 45.01088 & 78.34945 & $<0.0001^{* * *}$ \\
\hline Residual & 11.48977 & 20 & 0.574489 & & 0.2214 \\
\hline Lack of Fit & 9.876124 & 15 & 0.658408 & & 2.040121 \\
\hline Pure Error & 1.61365 & 5 & 0.32273 & & \\
\hline Cor Total & 191.5333 & 24 & & & \\
\hline
\end{tabular}

*** Significant at $1 \%$ level

Table 14: ANOVA for Linear Mixture Model on energy content (mango).

\begin{tabular}{|c|c|c|c|c|c|c|}
\hline Response & 2 & Calori & & & & \\
\hline \multicolumn{7}{|c|}{ ANOVA for Linear Mixture Model } \\
\hline \multicolumn{7}{|c|}{ *** Mixture Component Coding is L_Pseudo. ${ }^{* * *}$} \\
\hline \multicolumn{7}{|c|}{ Analysis of variance table [Partial sum of squares - Type III] } \\
\hline & Sum of & & Mean & $\mathbf{F}$ & p-value & \\
\hline Source & Squares & Df & Square & Value & Prob> F & \\
\hline Model & 2216.672 & 4 & 554.1679 & 60.97904 & $<0.0001$ & Significant \\
\hline Linear Mixture & 2216.672 & 4 & 554.1679 & 60.97904 & $<0.0001$ & \\
\hline Residual & 181.7569 & 20 & 9.087843 & & & \\
\hline Lack of Fit & 143.6609 & 15 & 9.577392 & 1.257008 & 0.4305 & not significant \\
\hline Pure Error & 38.09598 & 5 & 7.619195 & & & \\
\hline Cor Total & 2398.429 & 24 & & & & \\
\hline
\end{tabular}


Journal of Dairy \& Veterinary Sciences

Table 15: ANOVA for Linear Mixture Model on energy content.

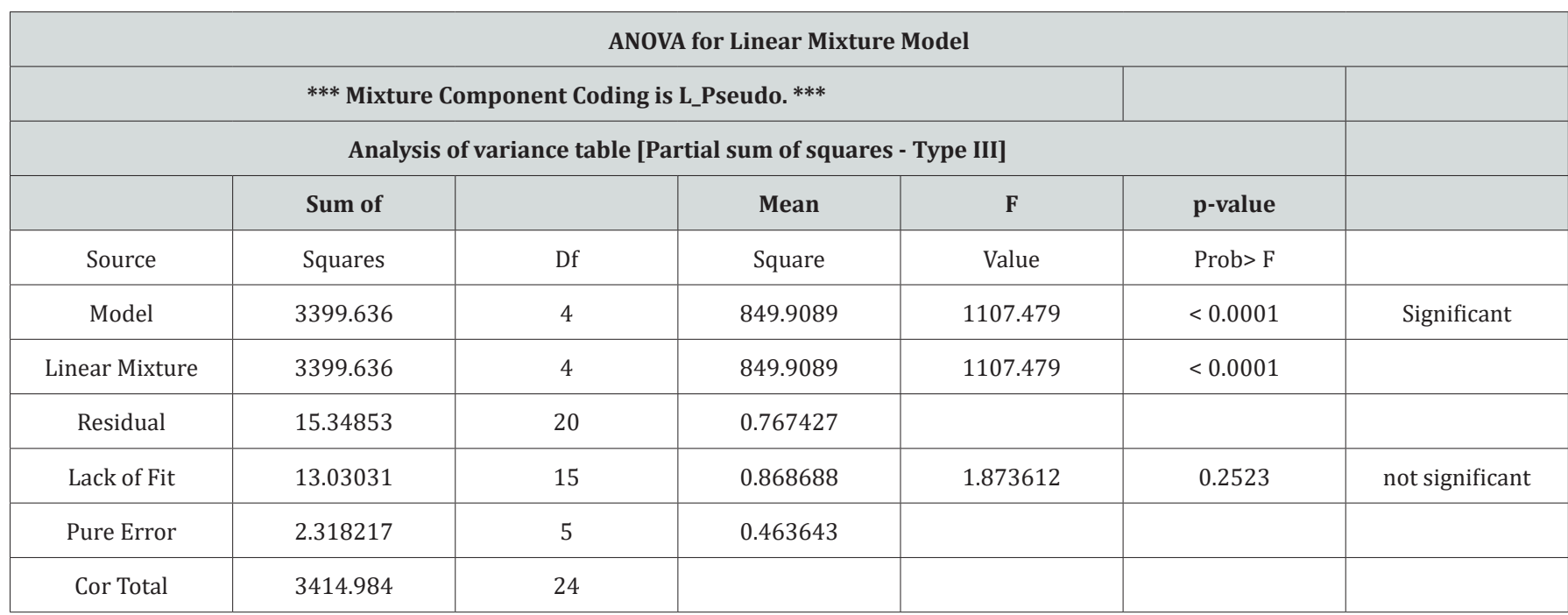

Final equation in terms of actual components:

Energy $=3.455244^{*}$ Corn $+3.398012 *$ Rice+3.433454* $\mathrm{DFSF}+3.700634 * \mathrm{SPI}+4.767625^{*}$ Dairy whiteners (10) for DW

Energy $=3.846363^{*} \quad$ Corn $+3.693403^{*} \quad$ Rice $+4.073597^{*}$ DFSF+3.817815* SPI+1.168505* Fruits (11) for mango

Energy $=3.637284^{*} \quad$ Corn $+3.684187^{*} \quad$ Rice $+3.716799 *$ DFSF+3.825296* SPI+0.541524*Vegetable (12) for spinach

From the regression equation (7), regression coefficient is highest for DW (4.767) indicating its larger effect on energy content of the DW which is also corroborated to its high fat content. However, mango-based products; DFSF (4.073) had more effect on energy value rather than mango. While for spinach-based product, except spinach all variable ad almost equal importance for energy value of the products (regression coefficient: 3.63-3.82). From the response plot (Figure 6), it may be seen that energy content was highest at 30,34 and $11.42 \%$ of corn flour, rice flour and DFSF beyond which the value decreased.

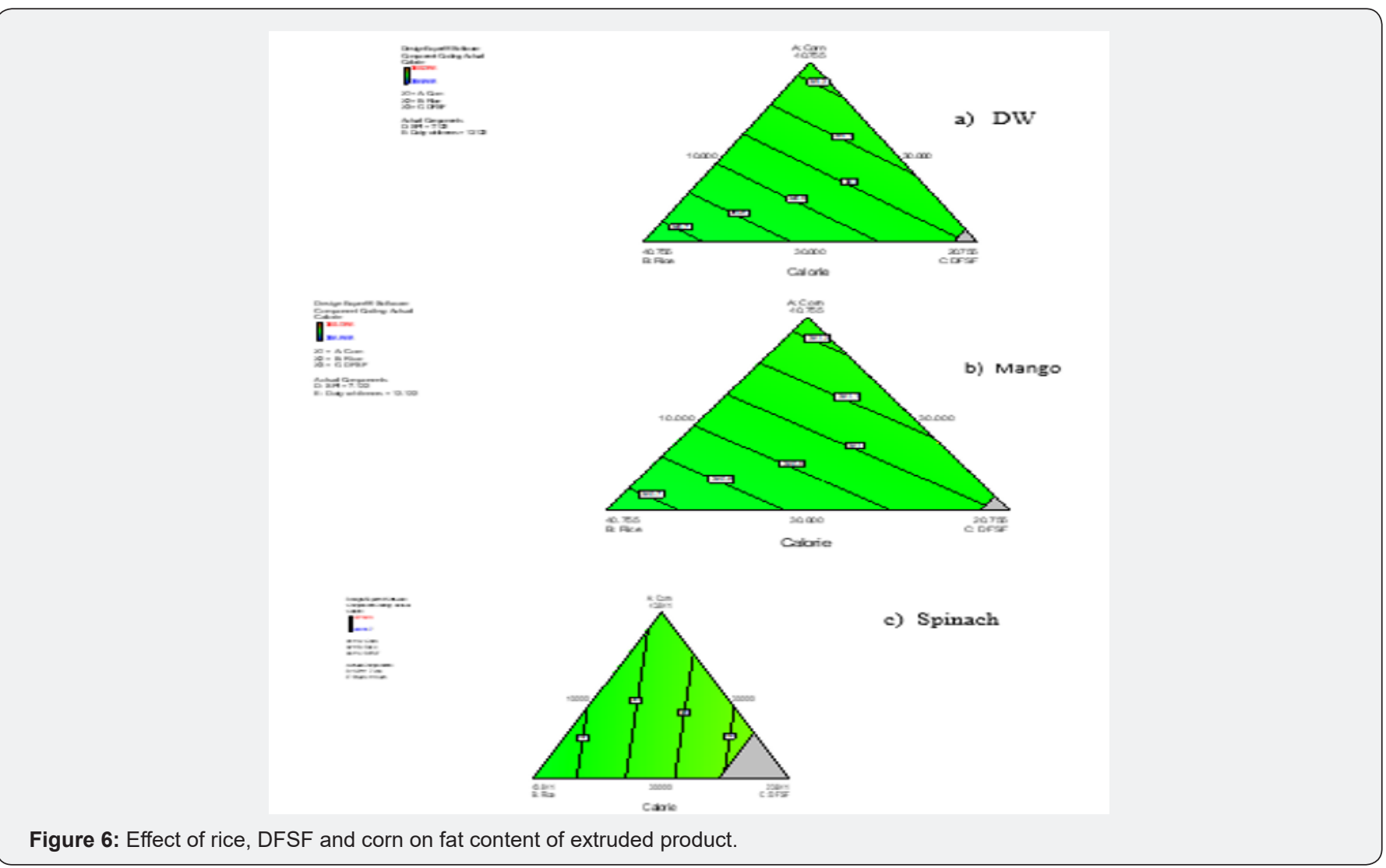




\section{Journal of Dairy \& Veterinary Sciences}

\section{Carbohydrate}

Generally, carbohydrate content depends on corn flour and rice flour where its value ranged between 59.95 and $66.59 \%$ for DW, 59.92 and $69.50 \%$ for mango, and57.32and $69.00 \%$ for spinach-based products. Using student's t-test, it was found that mean carbohydrate content of all products was statistically non-significant $\left(\mathrm{P}<0.19, \mathrm{t}_{\text {stat }}=1.3\right)$. Carbohydrate contents of the products were highly affected by corn flour and rice flour because corn rice was major source of carbohydrate. To fit the response, quadrat- ic model for mango and linear model for DW and spinach-based products are well represented as shown in ANOVA (Tables 16-18). The model was significant $(\mathrm{p}<0.001)$ with highest coefficient of determination $\left(R^{2}>0.99\right)$ of all the dependent parameters. From Table 16, it is observed that the interaction of corn*rice, corn*SPI, rice* DFSF, rice*SPI, DFSF*SPI and SPI*spinach are significant $(\mathrm{P}<0.05)$. The regression equation describing the effect of the process variables on the carbohydrate content of product in terms of actual level of the variables are given as:

Table 16: ANOVA for Linear Mixture Model on carbohydrate content.

\begin{tabular}{|c|c|c|c|c|c|c|}
\hline Response & 4 & Carbohy & & & & \\
\hline \multicolumn{7}{|c|}{ ANOVA for Quadratic Mixture Model } \\
\hline \multicolumn{7}{|c|}{ *** Mixture Component Coding is L_Pseudo. *** } \\
\hline \multicolumn{6}{|c|}{ Analysis of variance table [Partial sum of squares - Type III] } & \\
\hline & Sum of & & Mean & $\mathbf{F}$ & p-value & \\
\hline Source & Squares & Df & Square & Value & Prob $>$ F & \\
\hline Model & 192.9912 & 14 & 13.78508 & 50.95376 & $<0.0001$ & Significant \\
\hline Linear Mixture & 180.2058 & 4 & 45.05146 & 166.5236 & $<0.0001$ & \\
\hline Corn*Rice & 2.074498 & 1 & 2.074498 & 7.667959 & 0.0198 & \\
\hline Corn*DFSF & 0.477679 & 1 & 0.477679 & 1.765642 & 0.2134 & \\
\hline Corn*SPI & 2.721585 & 1 & 2.721585 & 10.05979 & 0.0100 & \\
\hline Corn*spinach & 0.704806 & 1 & 0.704806 & 2.605173 & 0.1376 & \\
\hline Rice* DFSF & 1.496217 & 1 & 1.496217 & 5.530461 & 0.0405 & \\
\hline Rice*SPI & 2.952919 & 1 & 2.952919 & 10.91487 & 0.0080 & \\
\hline Rice*spinach & 0.000447 & 1 & 0.000447 & 0.001651 & 0.9684 & \\
\hline DFSF*SPI & 1.818544 & 1 & 1.818544 & 6.721879 & 0.0268 & \\
\hline DFSF*spinach & 0.124259 & 1 & 0.124259 & 0.459299 & 0.5133 & \\
\hline SPI*spinach & 3.703789 & 1 & 3.703789 & 13.6903 & 0.0041 & \\
\hline Residual & 2.70541 & 10 & 0.270541 & & & \\
\hline Lack of Fit & 1.202254 & 5 & 0.240451 & 0.79982 & 0.5938 & not significant \\
\hline Pure Error & 1.503156 & 5 & 0.300631 & & & \\
\hline Cor Total & 195.6966 & 24 & & & & \\
\hline
\end{tabular}

Table 17: ANOVA for Linear Mixture Model on carbohydrate content.

\begin{tabular}{|c|c|c|c|c|c|c|}
\hline \multicolumn{5}{|c|}{ *** Mixture Component Coding is L_Pseudo. ${ }^{* * *}$} & & \\
\hline \multicolumn{6}{|c|}{ Analysis of variance table [Partial sum of squares - Type III] } & \\
\hline & Sum of & & Mean & $\mathbf{F}$ & p-value & \\
\hline Source & Squares & Df & Square & Value & Prob $>$ F & \\
\hline Model & 95.2794 & 4 & 23.81985 & 63660000 & $<0.0001$ & significant \\
\hline Linear Mixture & 95.2794 & 4 & 23.81985 & 63660000 & $<0.0001$ & \\
\hline Residual & 0 & 20 & 0 & & & \\
\hline Lack of Fit & 0 & 15 & 0 & & & \\
\hline Pure Error & 0 & 5 & 0 & & & \\
\hline Cor Total & 95.2794 & 24 & & & & \\
\hline
\end{tabular}




\section{Journal of Dairy \& Veterinary Sciences}

Table 18: ANOva for Linear Mixture Model on carbohydrate content.

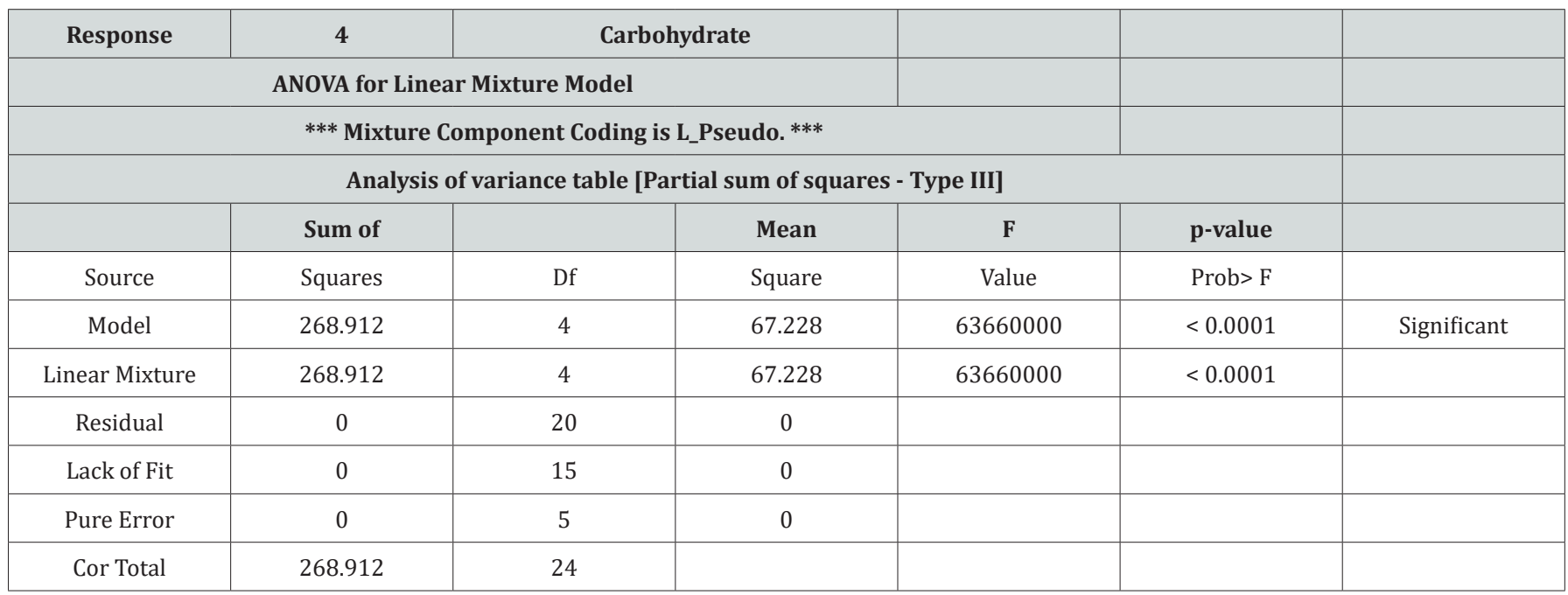

Final equation in terms of actual components:

Carbohydrate $=0.694 *$ Corn $+0.814 *$ Rice $+0.416 \mathrm{DFSF}+0.032 *$ SPI+0.554* Dairy whiteners (13) for DW

Final Equation in Terms of Actual Components:

Carbohydrate $=0.56164 *$ Corn $+0.352119 *$ Rice- $0.9141 *$ DFS$\mathrm{F}+16.50373$ Fruits $+0.015566^{*}$ Corn * Rice+0.018329* Corn * DFSF-0.1889* Corn * SPI-0.02553* Corn * Fruits $+0.032215^{*}$ Rice *
DFSF-0.1944* Rice * SPI+0.000582 * Rice * Fruits-0.15248* DFSF * SPI-0.01602* DFSF * Fruits-0.22741* SPI * Fruits

(14) for mango

Final Equation in Terms of Actual Components:

Carbohydrate $=0.73196 *$ Corn $+0.85196 *$ Rice $+0.45396 *$ DFS F+0.06996*SPI+0.09896* Vegetable (15) for spinach

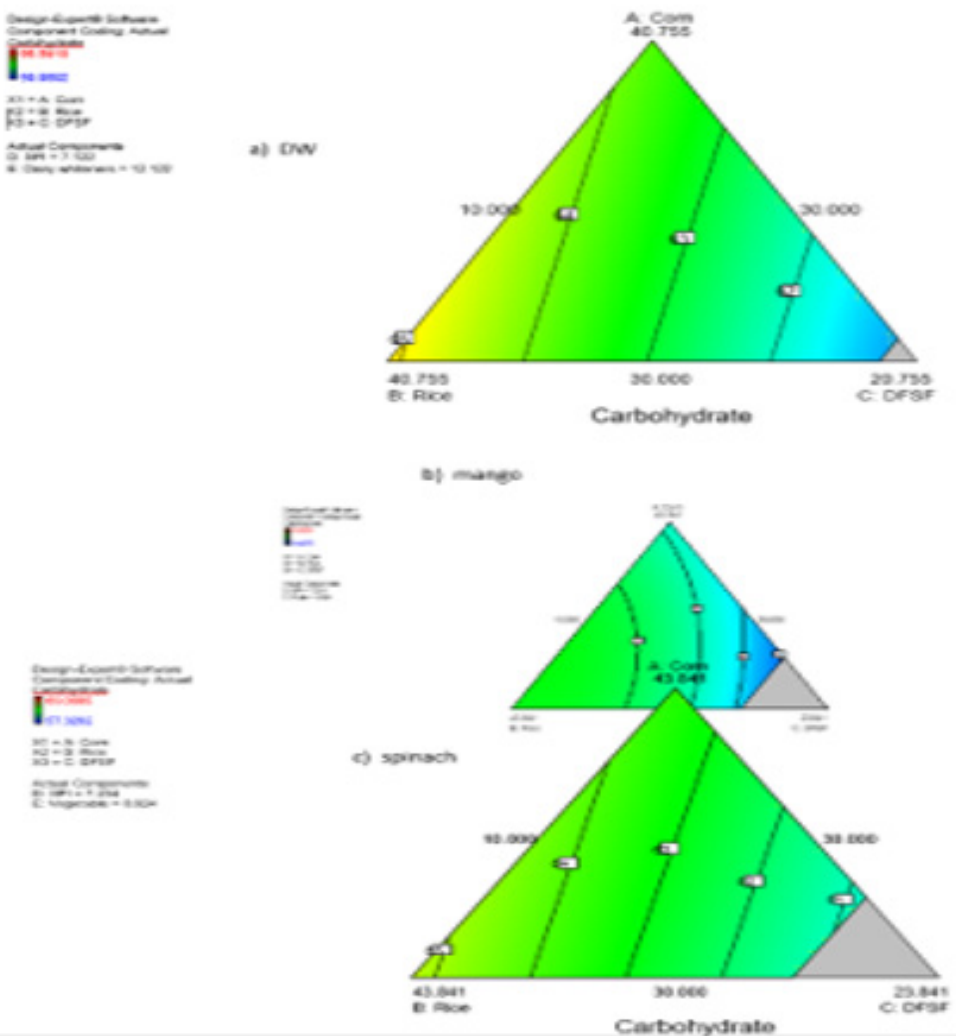

Figure 7: Effect of rice, DFSF and corn on carbohydrate content of extruded product. 
From eq. 13, the regression coefficients of interaction terms corn * SPI, corn * fruits, rice * SPI, DFSF * fruits and SPI * fruits are negative suggested that increase and decrease of these process parameters resulted in decrease and increase of carbohydrate content it is found that From the response surface graph (Figure 7), it may be seen that increase in corn flour and rice flour enhanced the carbohydrate content, being maximum at 41.8, 31.6 and 10.0 $\%$ of corn flour, rice flour and DFSF keeping a constant amount of DFSF and SPI at 12.122 and $7.12 \%$ level indicating minimum carbohydrate content with the combined increase of above variables. The reason may be due to high degree of starch gelatinisation at pre-setted machine parameters beyond which larger fragments of fibre molecules from starch of this flour may be sheared off during extrusion [27] and the fragments could unite to form large insolu- ble complexes or Maillard compounds generally termed as lignin causing lesser availability of carbohydrate compounds. A similar behaviour was also found for mango and spinach-based products.

\section{Specific Case of Most Acceptable Combinations of} Extruded Products

Soy fortified function extruded products were developed using rice flour, corn flour, DFSF, fruit powder, vegetable powder, SPI and dairy whiteners with optimum combination using response surface modeling. Many combinations of the developed products were found acceptable to the consumers; however, some most acceptable combinations from the above ingredients (Table 19) were taken for further analysis and storage study. Addition of $10 \%$ moisture was found optimum.

Table 19: Some most acceptable combination of extruded products.

\begin{tabular}{|c|c|c|c|}
\hline Trial No & Combinations of raw materials & Ratio & Sample \\
\hline 1. & Corn: Rice: DFSF: DW: SPI & $35: 35: 15: 10: 5$ & S-2 \\
\hline 2. & Corn: Rice: DFSF: Carrot: SPI & $40: 30: 15: 10: 5$ & S-3 \\
\hline 3. & Corn: Rice: DFSF: Spinach: SPI & $35: 40: 10: 10: 5$ & S-4 \\
\hline 4. & Corn: Rice: DFSF: Mango: SPI & $38: 32: 15: 10: 5$ & C \\
\hline 5. & Control: Corn: Rice & $50: 50$ & \\
\hline
\end{tabular}

\section{Nutritive Value of Soy Extruded Snacks based on Chemical Composition}

The snacks prepared with different levels of soybean was analyzed for protein, fat, carbohydrates, moisture content, Ash content, and energy values (Table 20).

Table 20: Nutritive values of accepted extruded snack products.

\begin{tabular}{|c|c|c|c|c|c|c|}
\hline Trial No. & Protein (\%) & Fat (\%) & MC (\%), db & Ash (\%) & Carbohydrate (\%) & Energy (kcal) \\
\hline S-1 & 19.95 & 7.15 & 1.8 & 5.5 & 61.12 & 432.18 \\
\hline S-2 & 18.05 & 5.32 & 1.9 & 6.5 & 63.22 & 418.05 \\
\hline S-3 & 16.45 & 8.40 & 1.8 & 4.5 & 61.95 & 451.57 \\
\hline S-4 & 19.25 & 4.69 & 2.1 & 5 & 64.29 & 414.90 \\
\hline Control & 10.85 & 6.55 & 2.1 & 4 & 40.05 & 440.60 \\
\hline
\end{tabular}

\section{Protein}

The observation in respect to protein content of soy extruded snacks is tabulated and graphically represented Fig. 8. It is revealed that, there was increase in protein level by addition the DFSF and SPI level in snacks. Soy powder blended extruded snacks recorded maximum protein 19.95 percent in S-1 sample and minimum protein of 10.85 per cent in control sample.

\section{Fat}

The observation in respect to fat content of extruded soysnacks is presented in Table 20. It is evident that there was increase in fat level by oil frying in snacks. Soy fortified snacks recorded maximum 8\% in S-3 sample and $6.55 \%$ in control sample.

\section{Carbohydrates}

The observation in respect to carbohydrate content of extruded snacks is presented in Table 20. It is evident that there was decrease in carbohydrate level by increasing the DFSF and SPI level in snacks. The soy fortified snacks recorded minimum $61.12 \%$ in S-1 sample and maximum carbohydrate of $70.05 \%$ in control sample. Increased in the carbohydrate was found in S-2 and S-4 sample by adding DFSF and SPI.

\section{Energy value}

The data pertaining to energy value content of extruded soysnacks are presented in the Table 20. It is observed that there was increase in energy value by increasing the soy flour level in snacks. Soy powder blended snacks recorded maximum $451.18 \mathrm{Kcal}$ in 
S-3 sample and minimum energy of $414.9 \mathrm{Kcal}$ in S-4 sample. Increased in the calorie by adding the DFSF and SPI were found in the samples.

\section{Moisture content}

From Table 20, It is evident that the moisture content ranges of the samples are varied between 1.8 to $2.1 \%$. Moisture content of product is affected by ingredients.

\section{Ash Content}

From Table 20, it is revealed that as the quantity of DFSF added, ash content also was increased. Ash content recorded maximum $6.5 \%$ in S-2 sample and minimum $4 \%$ in control sample. The graphical representation of protein, fat, carbohydrate content, energy-value, moisture-content and ash content of different treatments are represented in Figures 8-12.

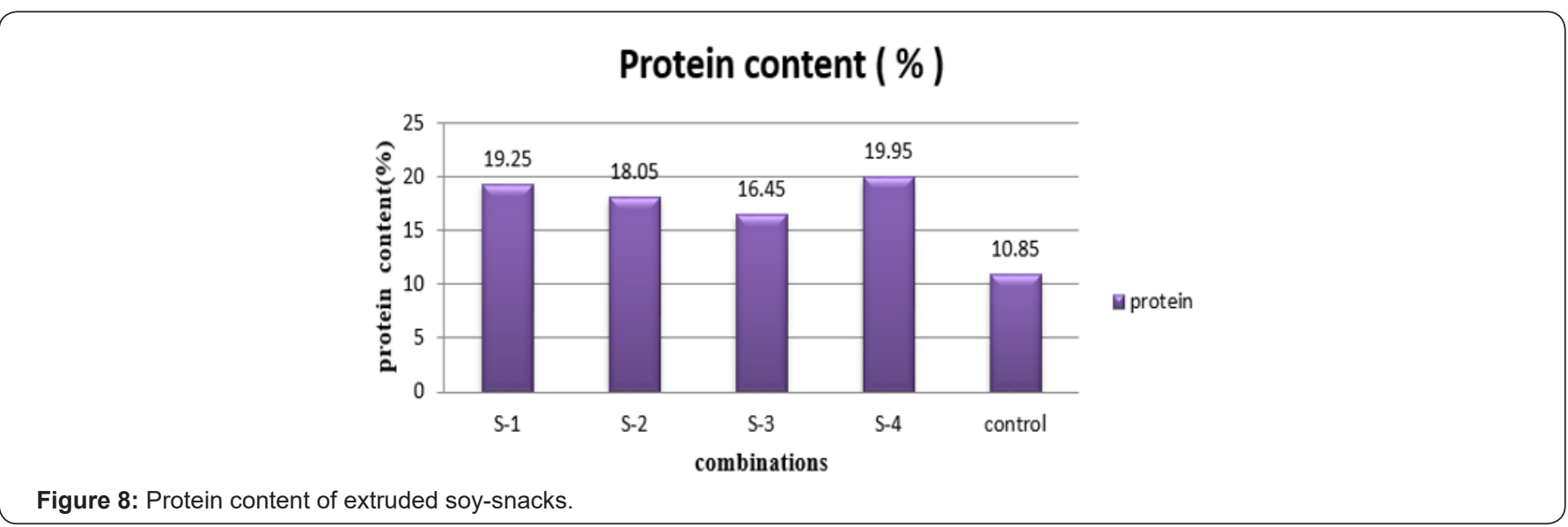

Figure 8: Protein content of extruded soy-snacks.

\section{Carbohydrate Content (\%)}

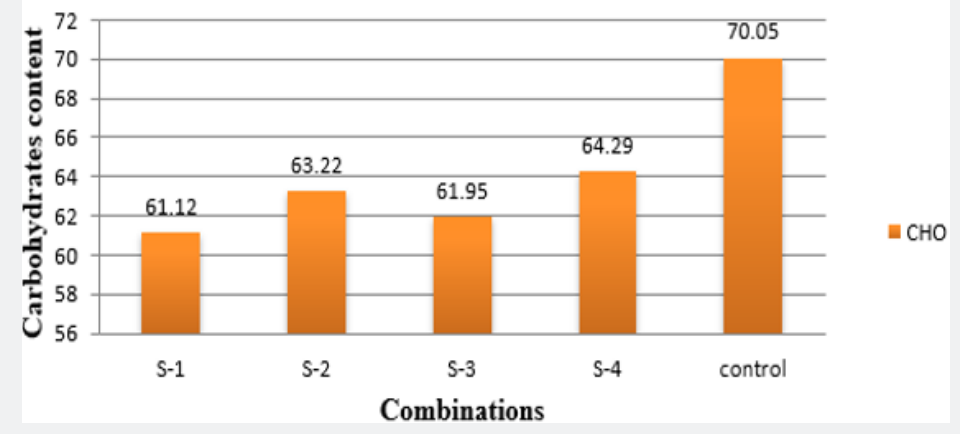

Figure 9: Carbohydrate content of extruded soy-snacks.

\section{Energy value (Kcal)}

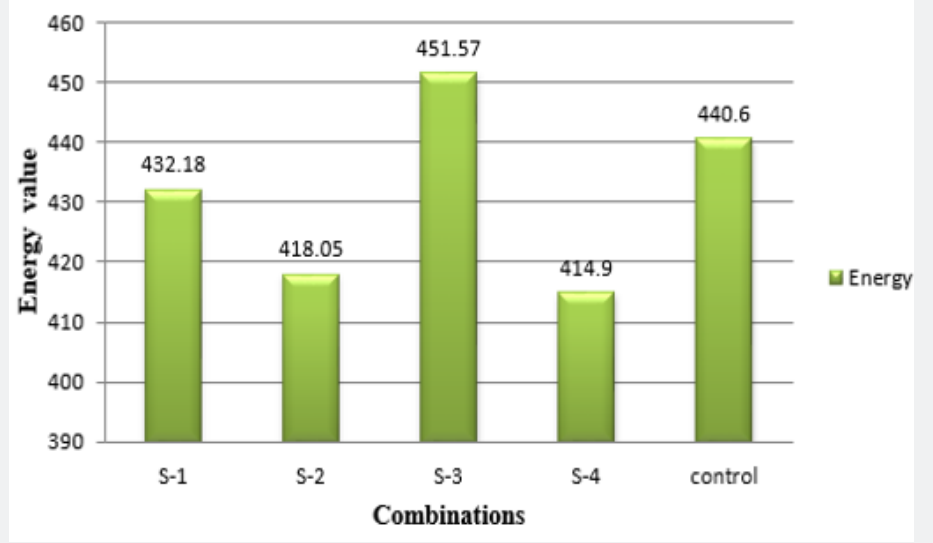

Figure 10: Energy/Calorie value of extruded soy-snacks. 


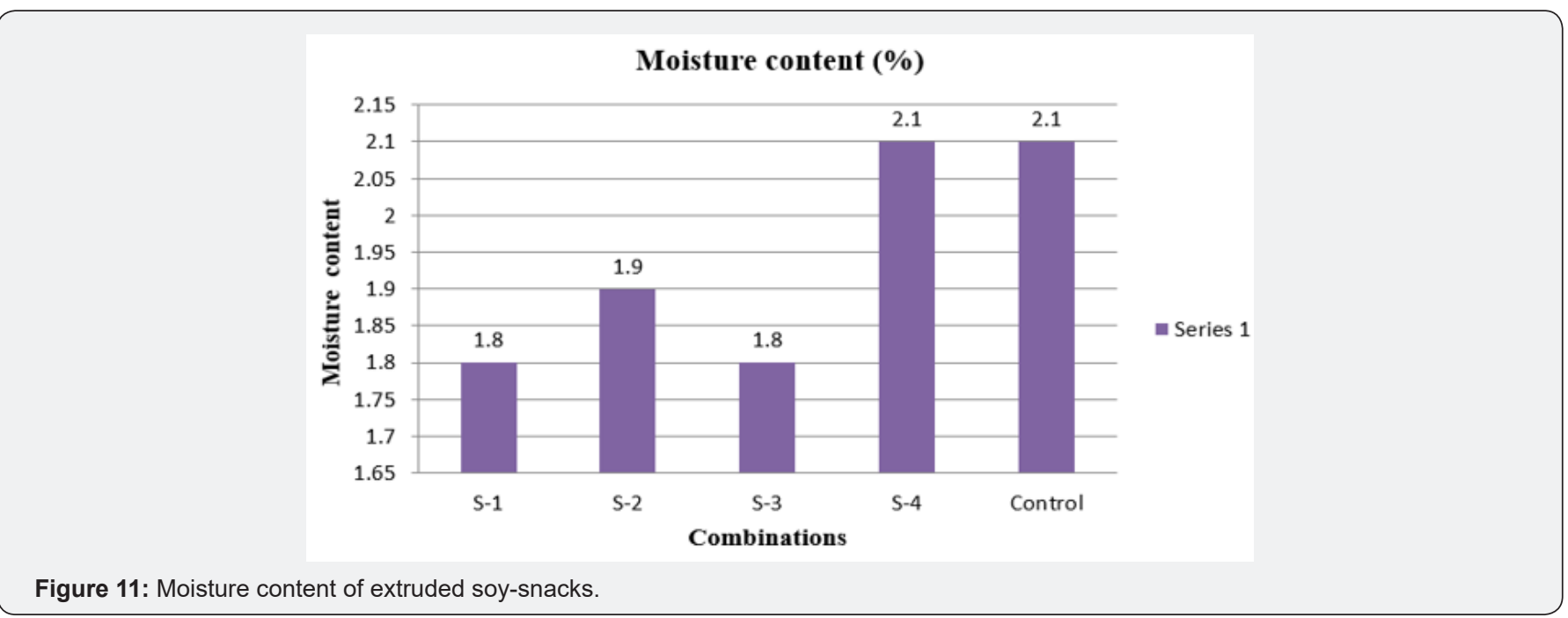

Figure 11: Moisture content of extruded soy-snacks

\section{Ash content (\%)}

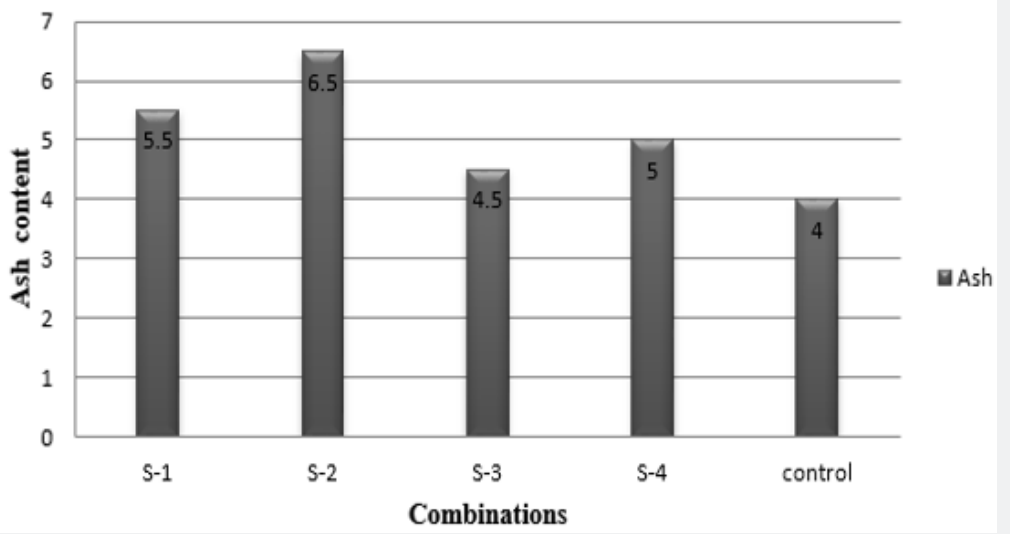

Figure 12: Ash content of extruded soy-snacks. Sensory evaluation of extruded snacks foods.

Sensory Evaluation of Extruded Snacks Foods

Table 21: Mean score for different characteristics of extruded snack products.

\begin{tabular}{|c|c|c|c|c|c|}
\hline \multirow{2}{*}{ Characters } & \multicolumn{5}{|c|}{ Combinations, } \\
\cline { 2 - 6 } & Control & S-1 & S-2 & S-3 & $6.7 \pm 0.71$ \\
\hline Taste & $7.0 \pm 05$ & $6.9 \pm 0.5$ & $7.0 \pm 0.98$ & $7.3 \pm 1.14$ & $6.7 \pm 0.5$ \\
\hline Texture & $7.4 \pm 0.69$ & $7.2 \pm 0.69$ & $7.1 \pm 0.98$ & $6.9 \pm 0.57$ \\
\hline Flavour & $7.1 \pm 0.41$ & $6.8 \pm 0.26$ & $6.7 \pm 0.57$ & $6.5 \pm 1.1$ & $6.4 \pm 0.57$ \\
\hline Colour & $6.9 \pm 0.14$ & $7.0 \pm 0.98$ & $6.4 \pm 0.12$ & $6.6 \pm 0.63$ & $6.9 \pm 0.57$ \\
\hline Appearance & $7.1 \pm 05$ & $6.9 \pm .07$ & $6.8 \pm 1.64$ & $6.7 \pm 1.71$ & $6.5 \pm 1.06$ \\
\hline Overall acceptability & $7.1 \pm 0.69$ & $7.0 \pm 0.88$ & $6.8 \pm .03$ & 6.85 \\
\hline
\end{tabular}

After seasoning coating the snack with roasted in different flavors, the snack samples were subjected to sensory evaluation. The samples of extruded soy-snacks were evaluated by using the standard scorecard. The assessment was done by studying the characters like color, flavor, taste and overall acceptability. Results revealed that with increase in the level of DFSF and SPI there is variation in sensory score related to colour, flavour, taste, texture/ mouth feel and overall acceptability [28-30]. Amongst various levels of DFSF, and SPI used in blend for the preparation of snacks, the highest overall score obtained was 7.0 for snacks prepared with the level of 10 per cent DFSF and 5 per cent SPI (S-1). The results show that the utilization of soy powder at $10 \%$ DFSF and 5 $\%$ SPI level reported maximum scores with respect to all sensory characters (Table 21). The substitution of all soy protein sources 
in snacks gave significant difference $(\mathrm{P} \leq 0.05)$ in terms of general appearance suitability of colour and overall acceptability from control formula. On the other hand, there were no significance difference $(\mathrm{P} \leq 0.05)$ among control sample and DFSF, and SPI formulas in terms of texture/ mouth feel, respectively. The general appearance of soy protein enriched extruded snacks showed no significant difference $(\mathrm{P} \leq 0.05)$ among snacks with any soy protein source.

\section{Textural Properties Analysis of Extruded Snack Products}

Table 22: Textural properties of extruded snack foods.

\begin{tabular}{|c|c|c|c|c|c|}
\hline Sample & Hardness & Springiness & Cohesiveness & Gumminess & Chewiness \\
\hline S-1 & 7.14 & 0.88 & 0.33 & 2.39 & 2.10 \\
\hline S-2 & 6.72 & 0.04 & 0.01 & 0.07 & 0.03 \\
\hline$S-3$ & 5.44 & 0.80 & 0.36 & 1.96 & 1.57 \\
\hline S-4 & 7.46 & 0.84 & 0.55 & 4.17 & 3.53 \\
\hline Control & 7.25 & 0.30 & 0.17 & 1.29 & 0.39 \\
\hline
\end{tabular}

For S-1 sample, the dairy whiter (DW) effects on the hardness of snacks. It was harder in texture as compare to other samples but less than control. The S-2 sample containing carrot, was low in hardness and other parameters of texture as compare to control, but more in gumminess and chewiness. The $\mathrm{S}-3$ sample containing spinach also low in hardness and other parameters of texture as
Textural quality of the snack samples was examined for compression force (CF) by applying a TA-XT2i Texture Analyzer. P50 compression probe (50 $\mathrm{mm}$. dia. cylinder aluminium) was applied to measure compression force required for samples breakage which indicates hardness [31-33]. Testing condition was 5.0 $\mathrm{mm} / \mathrm{s}$ pre-test speed, $5.0 \mathrm{~mm} / \mathrm{s}$ test speed, $10.0 \mathrm{~mm} / \mathrm{s}$ post-test speed. Each measurement was conducted on $50 \%$ strain of individual. Force-time curves of the TPA, hardness, cohesiveness, stickiness, springiness, chewiness, gumminess and adhesiveness values were determined. The textural properties of all the samples are presented in following Table 22. compare to control but more in gumminess and chewiness. The S-4 sample containing mango bad the highest hardness but less than control. The reason for highest hardness in control sample may be due to combination of only corn and rice which was less in other textural properties. The graphical representation of samples is represented in Figure 13.
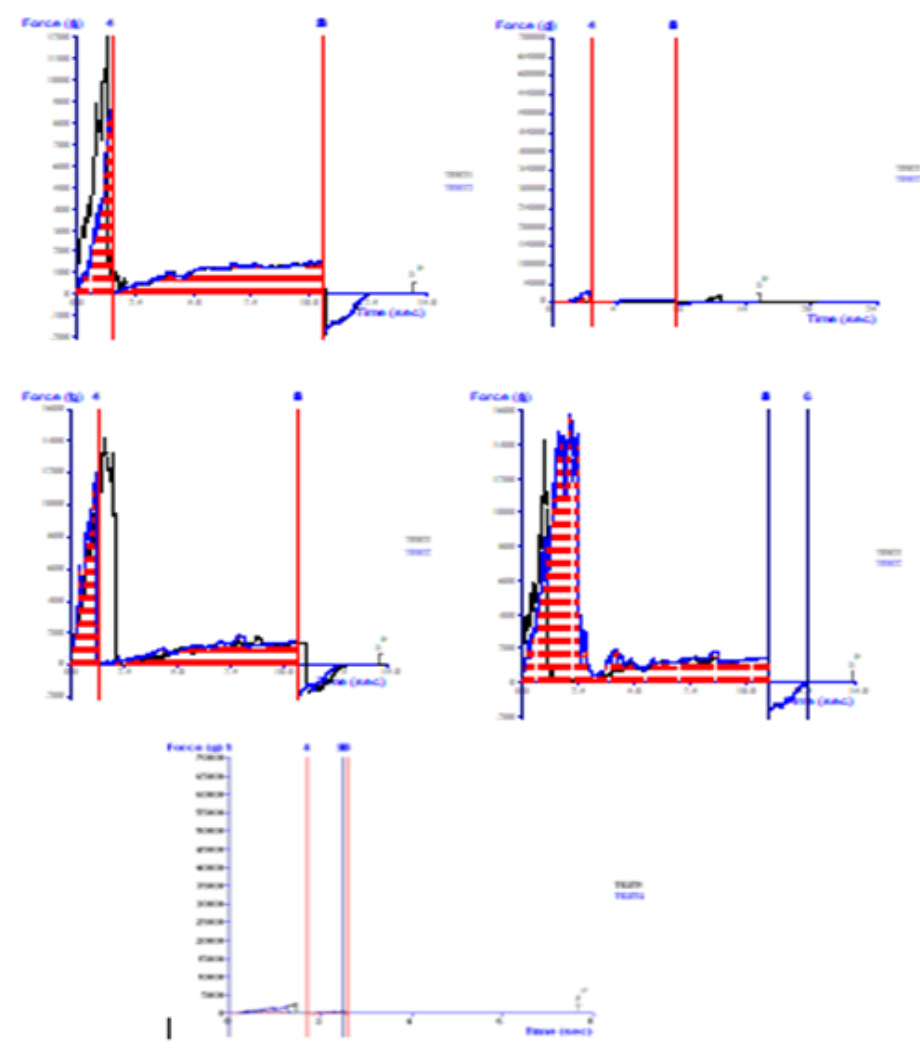

Figure 13: Textural properties of products (S1-S4) and control sample. 
The developed extruded snack foods rich in protein $(20 \%$ - 87\% increase) and low in fat are good protein supplement for school children and others. The products were evaluated using sensory chart with a panel of judges and the panel liked the product very much in terms of its texture, color, crispiness, appearance and taste. The storage study inferred that all the samples were suitable after six months in various packaging system, however, packaging in PET/PET met/LDPE kept the product with superior quality followed by PET met/LDPE and LDPE in terms of moisture content, crispness and sensory data. The developed products were provided to 100 school children of different age (10-18 yrs) group of Bhopal and collected the response for knowing the acceptability level of the product. The products were rated as 'very much liked'.

\section{Conclusion}

Extrusion-technology is gaining increasing popularity in the global agro-food processing industry, particularly in the food and feed sectors. In our study, starches and protein of different nature are co-extruded and the product parameters are influenced by synergetic effects. Such inexpensive, high energy value products may be valuable in feeding the hungry across the world as well as in promoting the health benefits of extruded foods. This study focuses to develop the process for production of nutritionally balanced formulated and functional snack foods which are successful in the market and meet the intended nutritional requirements and are also accessible to the vulnerable groups of the society at minimum possible cost. There was non-significant increase in moisture content and hardness of products during three month of storage. It was aimed to achieve this objective through use of abundantly available raw food ingredients having high nutrition such as cereals, soybean, dairy products and horticultural produce to minimize the cost and maximize nutrition.

\section{References}

1. Mangaraj S, Kadam DM (2007) Design and scale up of food extruder: Single screw. Processed Food Industry 10(11): 32-42.

2. Bhat R, Karim AA (2009) Exploring the nutritional potential of wild and underutilized legumes. Comp Rev Food Sci Food Safety 8:305-331.

3. Boye J, Zare F, Pletch A (2010) Pulse proteins: Processing, characterization, functional properties and applications in food and feed. Food Res Intl 43: 414- 431.

4. Mangaraj S, Tripathi MK, Ali N (2013) Hand Book of Nutraceuticals and Functional Food - Soybean as An Example. Satish Serial Publishing House, New Delhi, India, pp. 321.

5. Patil RT, Mangaraj S (2013) Processing Technology for Food Legumes. Satish Serial Publishing House, New Delhi, India, pp. 668.

6. Kadan RS, Bryant RJ, Pepperman AB (2003) Functional properties of extruded rice flours. J Food Sci 68: 1669-1672.

7. Giri SK, Mangaraj S (2012) Processing Influences on Composition and Quality Attributes of Soymilk and its Powder - A Review. Food Engg $\operatorname{Rev} 4$ (3): 149-164.

8. Giri SK, Mangaraj S (2014) Soymilk concentration by ultra-filtration: Effects of pore size and transmembrane pressure on filtration performance. Int J Food Sci Tech 49: 666-672.

9. Adesina AA, Sowhbagya CM, Bhattacharya S, Zakiuddin Ali S (1998)
Maize-soy-based ready-to-eat extruded snack food. J Food Sci Technol 35(1): 40-43.

10. Boonyasirikool P, Charunuch C (2010) Development of CorngritBroken Rice Based Snack Food by Extrusion Cooking. Kasetsart J Nat Sci 34: $279-288$.

11. Harper JM (1981) Extrusion of Foods. Boca Raton, CRC Press, FL, USA, 1: 2 .

12. Stojceska V, Ainsworth P, Plunkett A, Ibanoglu E, Ibanoglu S (2008) Cauliflower by-products as a new source of dietary fibre, antioxidants and proteins in cereal based ready-to-eat expanded snacks. J Food Eng 87: 554-563.

13. Altan A, McCarthy KL, Maskan M (2008) Evaluation of snack food from barley-tomato blends by extrusion processing. J Food Eng 84: 231-242.

14. Altan A, McCarthy KL, Maskan M (2008) Twin-screw extrusion of barleygrape pomace plends: Extrudate characteristics and determination of optimum processing conditions. J Food Eng 89: 24-32.

15. Upadhyay A (2008) thesis on Optimization of carrot pomace powder incorporation on extruded product quality by response surface methodology. Mahatma Gandhi Chitrakoot Gramoday Vishwavidyalys, Satna, Madhya Pradesh, India.

16. Upadhyay A, Sharma HK, Sarkar BC (2008) Characterization of dehydration kinetics of carrot pomace.

17. Khuri AI, Cornell JA (1987) Response Surfaces. Dekker, New York, USA.

18. Mangaraj S, Singh KP (2011) Optimisation of machine parameters for milling of pigeon pea using RSM. Food and Bioprocess Tech. An Int J 4: 762-769.

19. Mangaraj S, Singh KP (2011) Milling study of multiple pulses using CIAE dhal mill for optimal responses. J Food Proc Tech 2(2): 110-117.

20. Jha SK, Presad S (1997) Development of cereal-pulse based extruded food. J Agril Engng 34(1): 24-31.

21. Sudha ML, Rajeswari G, Rao GV (2011) Influence of defatted soyflour and whey protein concentrate on dough rheological characteristics and quality of instant vermicelli. J Texture Stud 42: 72-80.

22. Park CS, Baik BK (2004a) Cooking time of white salted noodles andits relationship with protein and amylose contents of wheat. Cereal Chem 81: $165-171$.

23. Sathe SK, Salunkhe DK (1981) Functional properties of the great Northern bean proteins: emulsion, foaming, viscosity, and gelation properties. J Food Sci 46:71-81.

24. Devi NL, Shobha S, Tang X, Shaur SA, Dogan H, et al. (2013) Development of Protein-Rich Sorghum-Based Expanded Snacks Using Extrusion Technology. Int J Food Prop 16: 263-276.

25. Pelembe LAM, Erasmus C, Taylor JRN (2002) Development of a ProteinRich Composite Sorghum-Cowpea Instant Porridge by Extrusion Cooking Process. LWT, Food Sci Tech 35: 120-127.

26. Li S, Zhang HQ Jin ZT, Hsieh F (2005) Textural Modification of Soya Bean/Corn Extrudates as Affected by Moisture Content, Screw Speed and Soya Bean Concentration. Int J Food Sci Tech 40: 731-741.

27. Leszek M, Zuilichem DJ (2011) Extrusion-Cooking and Related Techniques In: Extrusion-Cooking Techniques: Applications. Theory and Sustainability p. 1-24.

28. Kulkarni SD, Joshi KC, Venkatraj J, Venkatraghaven U (1997) Extrusion cooking of soy-cerealand other tuber blends: Product properties. J Food sci Technol 34(6): 509-512.

29. Messina M (2000) Soy foods and soybean phyto-estrogens (isoflavones) as possible alternatives to hormone replacement therapy (HRT). Eur J Cancer 36(4): 71-72. 
30. Moss R, Gore PJ, Murray IC (1987) The influence of ingredients and processing variables on the quality and microstructure of Hokien, Cantonese and instant noodles. Food Microstructure. 9:63-74.

31. Salcedo-Chávez B, Osuna-Castro JA, Guevara-Lara F, Domínguez Domínguez J, Paredes-López O (2002) Optimization of the isoelectric precipitation method to obtain protein isolates from amaranth (Amaranthuscruentus) seeds. J Agric Food Chem 50: 6515-6520.
32. Shils ME, Olson JA, Shike M, Ross AC (2002) Nutriciónensalud y enfermedad, Volumen II 9 A edition, McGrawHill Inter Americana Editors, S.A. de C.V. México, USA, pp. 1103-133.

33. Van Hung P, Maeda T, Tsumori R, Morita N (2007) Characteristics of fractionated flours from whole buckwheat grain using a gradual milling system and their application for noodle making. J Sci Food Agric 87: 2823-2829. 